\begin{abstract}
Iranica
Abstracta Iranica Revue bibliographique pour le domaine irano-aryen

Volume 34-35-36 | 2017

Comptes rendus des publications de 2011-2013
\end{abstract}

\title{
Vladimir A. Livšits. Engraved gems and bullae with Parthian inscriptions
}

\section{Rémy Boucharlat}

\section{(2) OpenEdition}

1 Journals

\section{Édition électronique}

URL : http://journals.openedition.org/abstractairanica/42290

DOI : 10.4000/abstractairanica.42290

ISSN : 1961-960X

Éditeur :

CNRS (UMR 7528 Mondes iraniens et indiens), Éditions de l'IFRI

\section{Référence électronique}

Rémy Boucharlat, «Vladimir A. Livšits. Engraved gems and bullae with Parthian inscriptions 》, Abstracta Iranica [En ligne], Volume 34-35-36 | 2017, document 30, mis en ligne le 30 juillet 2017, consulté le 26 septembre 2020. URL : http://journals.openedition.org/abstractairanica/42290 ; DOI : https://doi.org/ $10.4000 /$ abstractairanica.42290

Ce document a été généré automatiquement le 26 septembre 2020.

Tous droits réservés 


\title{
Vladimir A. Livšits. Engraved gems and bullae with Parthian inscriptions
}

\author{
Rémy Boucharlat
}

\section{RÉFÉRENCE}

Vladimir A. Livšits. « Engraved gems and bullae with Parthian inscriptions ». Parthica, 14, 2012 [2013], p. 171-188.

1 Étude des inscriptions que portent 11 sceaux d'époque parthe de divers musées, sans provenance connue, et rappel (p. 182-184) du classement par A. B. Nikitin, (« Parthian Bullae of Nisa ", Silk Road and Archaeology, 3, 1993-1994) des empreintes (de 1 à 7 ) sur 71 bulles de la Vieille Nisa. Les caractères sont similaires à ceux des ostraka des $\mathrm{II}^{\mathrm{e}} \mathrm{I}^{\mathrm{er}} \mathrm{s}$. av.n.è. Ils mentionnent des noms propres ou le titre de celui qui appose le sceau. Ces bulles datent, non pas des $\mathrm{II}^{\mathrm{e}}$ et $\mathrm{III}^{\mathrm{e}}$ s. d.n.è, comme le pensaient les inventeurs ( $\mathrm{M}$. Masson et G. Pugacenkova) mais bien de la deuxième moitié du $\mathrm{I}^{\mathrm{er}}$ avant et du $\mathrm{I}^{\mathrm{er}} \mathrm{s}$. d.n.è.

\section{AUTEURS}

RÉMY BOUCHARLAT

UMR 5133 CNRS-Université de Lyon 